\title{
Benefits of conservation-driven mowing for the EU policy species Gladiolus palustris Gaudin in mountain fen meadows: a case-study in the European Alps
}

\author{
Marco CANELLA ${ }^{*}$ (D) https://orcid.org/oooo-0002-8548-4109; $₫$ e-mail: marco.canella.3@gmail.com \\ Gianni POLONIATO2 ${ }^{\text {iD }}$ https://orcid.org/oooo-0002-9722-5235; e-mail: g.poloniato@dolomitipark.it \\ Cesare LASEN2 (iD https://orcid.org/oooo-0002-4182-7042; e-mail: cesarelasen@teletu.it \\ Simone ORSENIGO1 ${ }^{\text {iD }}$ https://orcid.org/oooo-0003-0348-9115; e-mail: simone.orsenigo@unipv.it \\ Graziano ROSSI ${ }^{\text {iD }}$ https://orcid.org/oooo-0002-5102-5019; e-mail: graziano.rossi@unipv.it

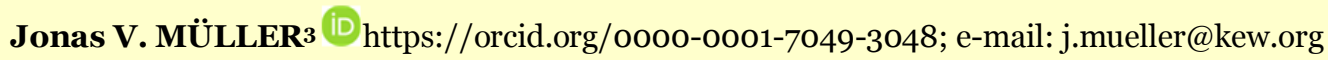 \\ Thomas ABELI4 (D) https://orcid.org/oooo-0003-3096-2035; e-mail:thomas.abeli@uniroma3.it \\ *Corresponding author \\ 1 Department of Earth and Environmental Sciences, University of Pavia, Via S. Epifanio, 14, 2710o Pavia, Italy \\ 2 Dolomiti Bellunesi National Park, Piazzale Zancanaro, 1 - 32032 Feltre, Italy \\ 3 Millennium Seed Bank, Conservation Science, Royal Botanic Gardens Kew, Ardingly RH17 6TN, West Sussex, UK \\ 4 Department of Science, University of Roma 3, Viale Guglielmo Marconi 446, oo146, Roma, Italy
}

Citation: Canella M, Poloniato G, Lasen C, et al. (2020) Benefits of conservation-driven mowing for the EU policy species Gladiolus palustris Gaudin in mountain fen meadows: a case-study in the European Alps. Journal of Mountain Science 17(9). https://doi.org/10.1007/s11629-019-5781-4

(C) The Author(s) 2020.

\begin{abstract}
The sword lily Gladiolus palustris Gaudin is protected on European level and listed in Annexes II and IV of the EC Habitat Directive 92/43/EEC. It grows in nutrient-poor, calcareous meadows in central and eastern Europe. Tree encroachment in montane meadows of the European Alps as a result of recent land use changes and the abandonment of traditional farming practices threaten the survival of this species. Conservation-driven mowing is considered a feasible conservation measure for maintaining high species diversity in abandoned semi-natural grasslands. To assess the effects of ten
\end{abstract}

\footnotetext{
Received: $11-$ Sep-2019

$1^{\text {st }}$ Revision: $12-$ Feb-2020

2nd Revision: 01-Apr-2020

$3^{\text {rd }}$ Revision: $14-$ May-2020

Accepted: 18-Jun-2020
}

years of biennial mowing on a grassland community in the Dolomiti Bellunesi National Park, Italy (Site of Community Importance, Natura 2000 network), ten $25 \mathrm{~m}^{2}$ plots were established whereby four plots were placed in the mowed area, four in the non-mowed area and two in a small non-mowed patch of grassland inside the mowed area. In each plot the following variables were recorded, total percentage of plant cover, percentage cover of woody species, percentage cover of herbaceous species, percentage cover and number of flowering ramets of $G$. palustris and a complete list of species and their percentage abundance. Mowed plots showed a higher species richness than non-mowed plots. The number of $G$. palustris flowering ramets and percentage cover increased manifold in mowed plots compared to nonmowed plots. The resumption of mowing for 
conservation purposes undertaken by the managing authority halted the process of tree encroachment and avoided a drastic change in plant composition. Periodic mowing (every second or third year) was demonstrated to be a cost-effective conservation measure in non-productive grasslands to keep grasses at bay in favour of forbs of high conversation value.

Keywords: Conservation management; Seminatural habitats; Habitat directive; Montane grassland; Natura 2000 network; Dolomiti Bellunesi National Park

\section{Introduction}

Traditionally, low productive grasslands in mountain areas are mowed once a year (Middleton et al. 2006). However in many places, this practice has become economically unsustainable where mechanisation is not possible for example due to difficult access and steep slopes (Török et al. 2011; Valkó et al. 2012). Conservation-driven mowing is an effective practice to maintain high species diversity in abandoned semi-natural grasslands, because it simulates traditional land management practices (Horak and Safarova 2015). It avoids the dominance of grasses and other graminoids and the often irreversible encroachment of shrubs and trees into open areas (Agnoletti 2007; Halada et al. 2011). Mowing is successfully applied in several protected areas, either on an experimental basis or as a specific conservation management tool (Balazsi 2016). However due to an impoverished soil seed bank and limited seed immigration (Stampfli and Zeiter 1999) or due to changes in soil properties (as a result of successional changes in vegetation coverage) (Swacha et al. 2018), mowing may not completely reverse the loss of plant species in those areas abandoned long ago. A timely resumption of traditional practices for conservation purposes is therefore the key in order to maintain semi-natural grasslands and species of conservation importance (target species sensu Kiehl et al. 2010) in good condition (Joyce 2014). Indeed, the impact of mowing on single plant species performance may differ across the vegetation structure, and beneficial effects might occur for some species or groups of species but might have negative effects on other species (Valkó et al. 2012). It is therefore essential to carefully assess the effects of conservation-driven mowing on target plant species and communities. Such assessments can monitor progress and eventually help adjust the used techniques for a more costeffective management of plant species and ecosystems. In addition, the implementation of conservation practices could interest valuable entities as endemic and sub-endemic, as well as relict species, or plants occurring at the edges of their geographical ranges. In this study, we evaluated the effect of conservation-driven mowing to preserve Gladiolus palustris in a montane environment in the Italian Alps. Specifically, we assessed the conservation status of a G. palustris population and the plant diversity after ten years of mowing in a species-rich wet meadow in the Dolomiti Bellunesi National Park (N-E Italy). We asked the following three questions, 1) is plant diversity higher in mowed than in non-mowed areas? 2) does G. palustris perform better in terms of abundance and number of flowering ramets in mowed than in non-mowed areas? 3) do other relevant species (i.e. endemic and sub-endemic, species characteristic for the habitat, locally protected species) benefit from conservationdriven mowing intended to conserve G. palustris? We hypothesised a general increase in plant diversity and a higher abundance of G. palustris and other species of conservation interest in mowed areas compared to non-mowed areas. $G$. palustris is listed in the European 'Habitat' Directive 92/43/EEC (Annex II and IV). As such, it provokes the designation of Special Areas of Conservation (SACs), the application of ad hoc feasible conservation measures and periodical monitoring of its conservation status in all EU Member States (Ostermann 1998). This is why the results presented here may have relevance for the conservation management in all 146 designated SACs (Special Areas of Conservation) located in 13 EU Member States where G. palustris naturally occurs (European Environmental Agency 2019).

\section{Material and Methods}

\subsection{Study species}

The sword lily Gladiolus palustris Gaudin (Iridaceae) is a bulbous geophyte. Its spherical 
corm reaches a diameter of $2-3 \mathrm{~cm}$ and is located about $10 \mathrm{~cm}$ deep in the soil. The species grows $30-$ $60 \mathrm{~cm}$ tall. It flowers in May-June. It is endemic to Europe, occurring in Central and Eastern Europe from France to Ukraine (EURO+MED 2018) and across a wide altitudinal range. The species typically grows in grasslands, pastures and wet meadows over nutrient-poor, calcareous soils (Sburlino et al. 1995; Da Canal et al. 2013). The cooccurring vegetation represents a key aspect in assessing restorations, since as a biotic factor it may influence the realized niche of target species. Habitat characterization and monitoring are particularly relevant for montane meadows, which are considered hotspots of biodiversity, because the richness in microhabitats allows the growth of specialized species with narrow realized niches (Czortek et al. 2018). Using the classification of the EU Habitat Directive 92/43/EEC, its habitats can be classified as H6410 (Molinia meadows on calcareous, peaty or clayey-silt-laden soils; Molinion caeruleae), H62Ao (Eastern subMediterranean dry grasslands; Scorzoneratalia villosae) and H6210 (Semi-natural dry grasslands and scrubland facies on calcareous substrates; Festuco-Brometalia). In the EU Red List of policy species (Bilz et al. 2011) G. palustris is assessed as Data Deficient (DD) however in several European countries, it is locally threatened: extinct (EX) in Slovakia, critically endangered (CR) in Czech Republic (Witkowski et al. 2003), endangered (EN) in Switzerland (Moser et al. 2002) and Germany (Metzing et al. 2018), near threatened (NT) in Italy (Rossi et al. 2016). Its population trend is declining over most of the historical range (Da Canal et al. 2003) and its conservation status is considered inadequate in Italy (Fenu et al. 2016). Threats affecting G. palustris (as well as other montane meadow forbs) are manifold and include, shrub and tree encroachment in montane meadows (Peter et al. 2009; Joyce 2014), intensive or heterogeneous grazing (Parolo et al. 2011; Wiesmar et al. 2017), human-mediated habitat destruction in mountain and lowland areas, and a change in precipitation regimes with increased drought at the edge of its area of distribution (e.g. Italy; Da Canal et al. 2003; Rossi et al. 2016; Buffa et al. 2016). In greater detail, the factors responsible for negative population trends of G. palustris in the study area are strictly connected to land use change and the abandonment of traditional land management regimes with grazing and mowing (Lasen et al. 2018a,b; Tallowin et al. 2005).

\subsection{Study area}

The study area on Mt. Grave is located in the outer Dolomites in the Dolomiti Bellunesi National Park (DBNP) in N-E Italy (Figure 1). It lies within the Site of Community Importance (SCI) IT3230083 "Dolomiti Feltrine e Bellunesi", which forms part of the European Natura 2000 Network. Monte Grave (N 46 $5^{\prime} 21.4^{\prime \prime}$, E $11^{\circ} 55^{\prime} 27.7^{\prime \prime} ; 1544 \mathrm{~m}$ asl.), located in the western parts of DBNP, is characterised by calcareous soils over limestone of the Maiolica Formation. The study area at an altitude between 1220 to $1280 \mathrm{~m}$ a.s.l. is characterised by slope angles ranging from 20 to $30^{\circ}$, while aspect ranges from $180^{\circ}$ to $222^{\circ}$ (S to $\mathrm{SW})$. At lower elevations up to about $1200 \mathrm{~m}$ a.s.l. Fagus sylvatica woodlands (mainly DentarioFagetum, with patches of Aremonio-Fagion) dominate the aspect, while the higher areas up to the summit are characterised by semi-natural habitats classified as Gladiolus palustrisMolinietum arundinaceae. This vegetation type is part of H62Ao (Eastern sub-Mediterranean dry grasslands; Scorzoneratalia villosae). Some areas of Mt. Grave can be assigned to H6210 (Seminatural dry grasslands and shrubland facies on calcareous substrates; Festuco-Brometalia). It is important to mention that $\mathrm{H} 6210$ is a habitat of high conservation interest for the alpine biogeographical region (Campagnaro et al. 2018). It is rich in plant species, including taxa of conservation interest such as Gladiolus palustris (Figure $2 \mathrm{C}, 2 \mathrm{D}, 2 \mathrm{E}$ ), and it is considered an important site for the presence of several wild orchid species such as Dactylorhiza maculata (L.) Soó subsp. fuchsii (Druce) Hyl. and Gymnadenia conopsea (L.) R.Br.. During the past centuries, meadows at higher altitudes had been managed by clear-cutting and mowing to allow sheep grazing and the production of hay. These traditional management practices were abandoned in the 1960-70 as the mountain area depopulated. This land use change resulted in the bush and tree encroachment of the montane meadows by woody species such as Betula pendula Roth, Larix decidua Mill, Corylus avellana L., Sorbus aria (L.) 


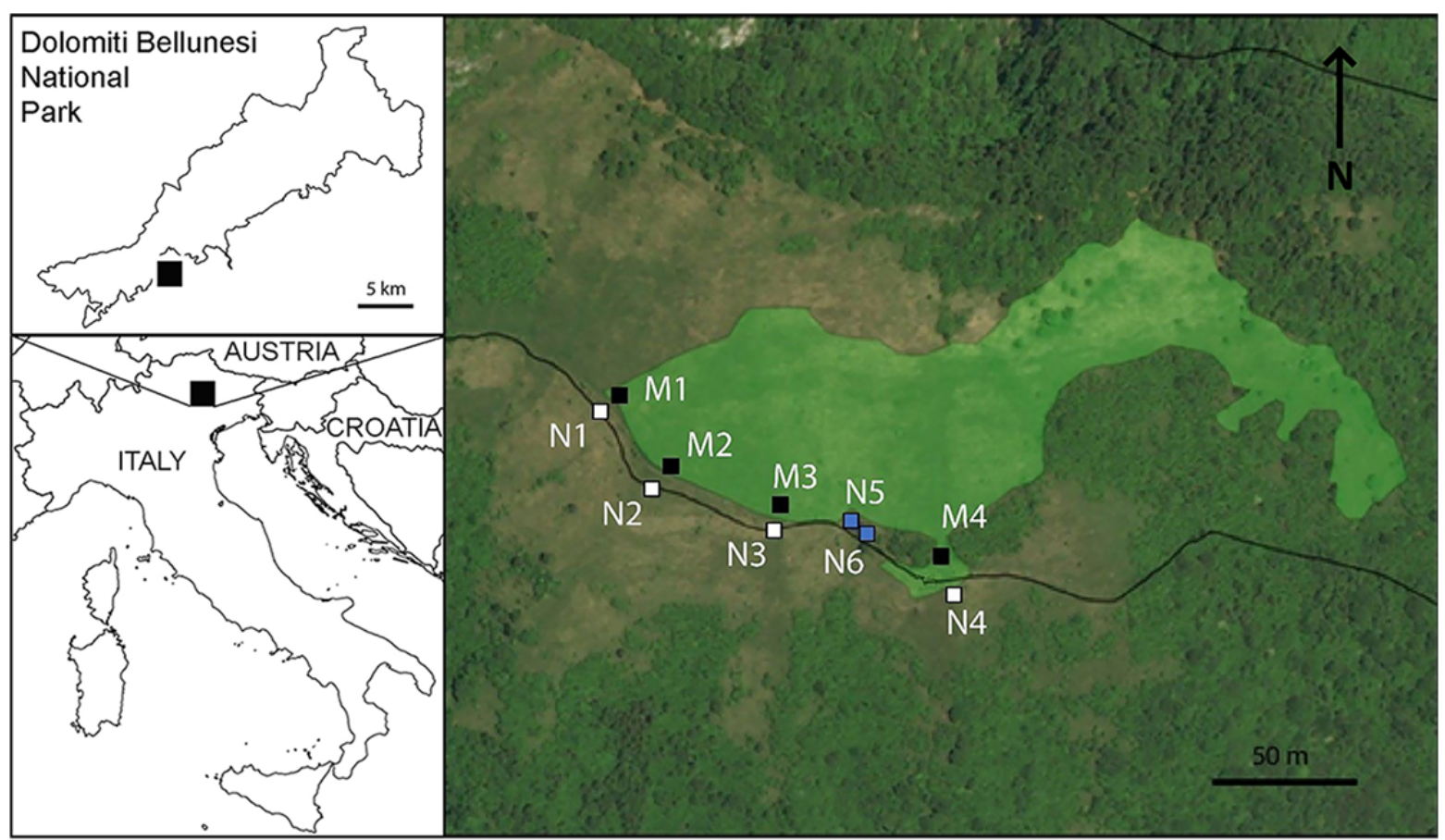

Figure 1 Study area. The shaded area in the main figure represents the mowed area on Mt. Grave (Dolomiti Bellunesi National Park), where mowed plots were established (black squares marked with the progressive M letter). The black line shows the National Park border. Non-mowed plots (white squares marked with progressive N) where established in the non-mowed areas just outside the National Park. Light blue squares represent non-mowed plots inside the mowed area.

Crantz and the expansion of beech woodlands (Figure 2A, 2B). The establishment of DBNP in 1993 allowed to adopt conservation management actions, including the removal of woody species and periodical mowing of species-rich meadows with the aim to restore and maintain the plant diversity. In addition, three large natural wildfires between 1975 and 2012 restricted the further expansion of woody species.

\subsection{Mowing treatments and survey}

Since 2009, DBNP has used mowing and cutting in an area of 21.6 ha on Mt. Grave to limit the expansion of grasses and other graminoid weeds and woody plants. In the first year, trees and shrubs were removed manually. Mowing is done every other year in late August-early September, according to the seed dispersal phenology of $G$. palustris. The vegetation is mowed at a height of $10-12 \mathrm{~cm}$ from ground, the cut material is not removed. No additional treatments (such as fertilization or sowing) are done. In 2018, ten $25 \mathrm{~m}^{2}$ plots were established on the southern and southsouth-eastern slopes of Mt. Grave to assess the effect after 10 years of mowing on the local population of $G$. palustris and on the grassland community more generally. The plots were distributed as following, four in the mowed area, four in the non-mowed area and two in a small non-mowed patch of grassland inside the mowed area (Figure 1). These last two plots were established to see whether mowing had an effect on adjacent non-mowed areas. Since we do not have historical data on the situation before the start of the conservation management actions in 2009, we assume that non-mowed areas represent the conditions as pre-2009 (or at least very close to them). In each plot, the following variables were recorded, total species percentage cover, percentage cover of woody species, percentage cover of herbaceous species, percentage cover and number of flowering ramets of G. palustris and a complete list of species and their percentage abundance (according to Van der Maarel 2015). Species cover is the cover of each plant species independently from the cover of other species. The sum of combined species cover can exceed $100 \%$. Using the lists of species, the species richness and the Shannon Index $\mathrm{H}$ were calculated $(\mathrm{H}=-$ $\Sigma_{i} p_{i} \ln \left(p_{i}\right)$ ), where $p i$ is the proportional abundance of the ith species; Shannon 1948). 

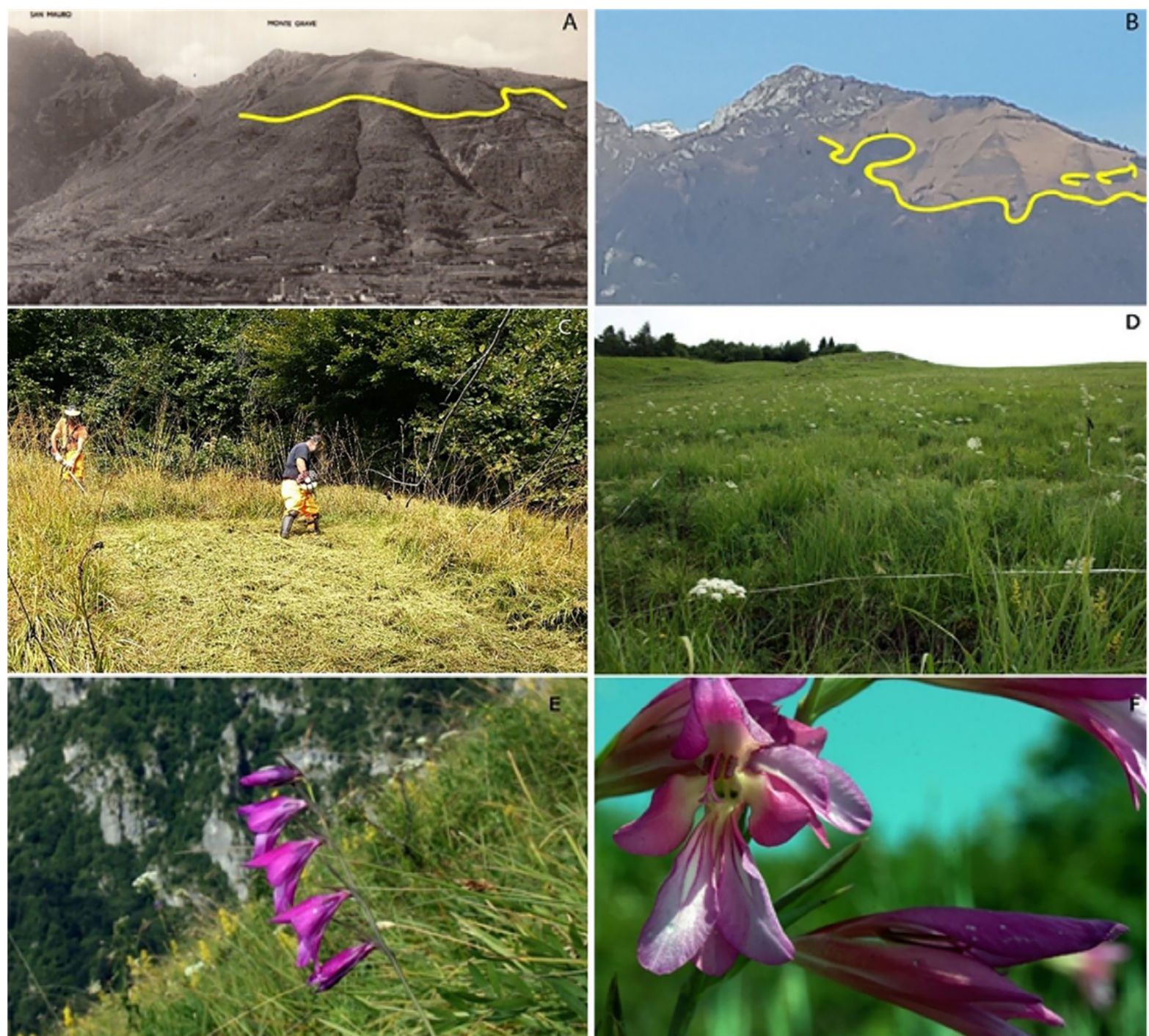

Figure 2 Mt Grave - comparison of the situation as shown on a postcard of 1963 and in 2018. The yellow line marks the woodland upper limit (A-B). Conservation-driven mowing performed by the staff of Dolomiti Bellunesi National Park (C). A mowed plot during the 2018 survey (D). G. palustris flowering ramets in the study area (E-F).

\subsection{Data analysis}

The effect of mowing on G. palustris and grassland vegetation was tested using a Generalised Linear Model (GLM), in which mowing was treated as the fixed factor, while slope and aspect were treated as co-variates. As vegetation parameters, we employed the cover and the number of flowering ramets of $G$. palustris, the total cover of herbaceous species and the total cover of woody species. Slope and aspect were recorded as environmental factors. Elevation was not considered a variable, since all mowed plots were situated at a higher elevation than nonmowed plots. However, the altitudinal difference is very small $(15.41 \pm 3.2 \mathrm{~m})$ and does very likely not affect the performance of G. palustris or any other variable. A linear distribution was employed. Moreover, two multiple linear regressions, with consideration of $G$. palustris cover and the number of ramets as response variables, and vegetation parameters and abiotic factors as predictors were performed to evaluate how parameters of cooccurring vegetation and abiotic factors influenced the performance of $G$. palustris. A Principal Component Analysis (PCA) was performed to correlate the performance of G. palustris with vegetation variables (total species percentage cover, percentage cover of woody species, percentage cover of herbaceous species, percentage cover and number of flowering ramets of $G$. palustris). Finally, a cluster analysis was performed to 
highlight similarities among plots based on the recorded species and their abundances. The BrayCurtis Index was used as compositional

dissimilarity index. PCA and cluster analysis were performed in PAST v3.20 (Hammer et al. 2001), while GLM and linear regressions were performed in SPSS v21.

\section{Results}

G. palustris is present on Mt. Grave with a flourishing population estimated to have more than 74.00o flowering ramets. The GLM analysis revealed a significant effect of mowing on species richness and Shannon Index, with mowed plots being richer and more diverse than non-mowed plots (Table 1; Figure 3). The effects of slope and aspect were never statistically significant, except when considering the percentage cover of the woody species and the Shannon Index. Independent of mowing treatment, woody species on Mt. Grave were mainly present on the south-south-eastern slope and almost absent on the southern slope, resulting in a stronger shrub encroachment on the former slope. Effect of mowing can also be seen from the PCA analysis, in which the first two axes account for more than $80 \%$ of the total variance (Figure 4). Mowed plots are distributed along an increasing gradient of species richness and Shannon Index, and according to the PCA, performance of $G$. palustris is negatively correlated with the percentage vegetation cover with both components, herbs and trees. The multiple regressions highlighted a significant positive
Table 1 Results from the GLMs on the effects of mowing on different grassland characteristics and the performance of Gladiolus palustris. Statistically significant effects are shown in bold. Degree of freedom is 1 in all cases.

\begin{tabular}{|l|l|l|l|l|} 
& \multicolumn{2}{l|l}{ Average values \pm (st.dev.) } & \multicolumn{2}{l|}{ GLM Statistics } \\
\cline { 2 - 5 } & Mowed & Non-mowed & Wald $\chi^{2}$ & $P$ \\
\hline G. palustris flowering ramets & $\mathbf{2 7 . 7 5} \pm \mathbf{( 3 2 . 5 4 )}$ & $\mathbf{3 . 0 0} \pm \mathbf{( 7 . 3 5 )}$ & $\mathbf{6 . 2 7 3}$ & $\mathbf{0 . 0 1 2}$ \\
\hline G. palustris cover (\%) & $\mathbf{4 . 0 0} \pm \mathbf{( 2 . 0 0 )}$ & $\mathbf{0 . 8 3} \pm \mathbf{( 2 . 0 4 )}$ & $\mathbf{8 . 2 0 8}$ & $\mathbf{0 . 0 0 4}$ \\
\hline Total cover (\%) & $166.50 \pm(37.86)$ & $183.0 \pm(27.31)$ & 2.208 & 0.137 \\
\hline Herbs cover (\%) & $149.50 \pm(37.00)$ & $162.7 \pm(19.13)$ & 0.937 & 0.333 \\
\hline Woody species cover (\%) & $17.00 \pm(3.16)$ & $20.33 \pm(18.97)$ & 3.459 & 0.063 \\
\hline Species richness & $\mathbf{4 5 . 0 0} \pm(\mathbf{3 . 1 6})$ & $\mathbf{3 0 . 8 3} \pm \mathbf{( 7 . 9 3 )}$ & $\mathbf{1 4 . 4 0 8}$ & $<\mathbf{0 . 0 0 1}$ \\
\hline Shannon index & $\mathbf{3 . 3 7 7} \pm(\mathbf{0 . 1 4})$ & $\mathbf{2 . 5 0 3} \pm(\mathbf{0 . 5 7})$ & $\mathbf{1 5 . 3 5 1}$ & $<\mathbf{0 . 0 0 1}$
\end{tabular}
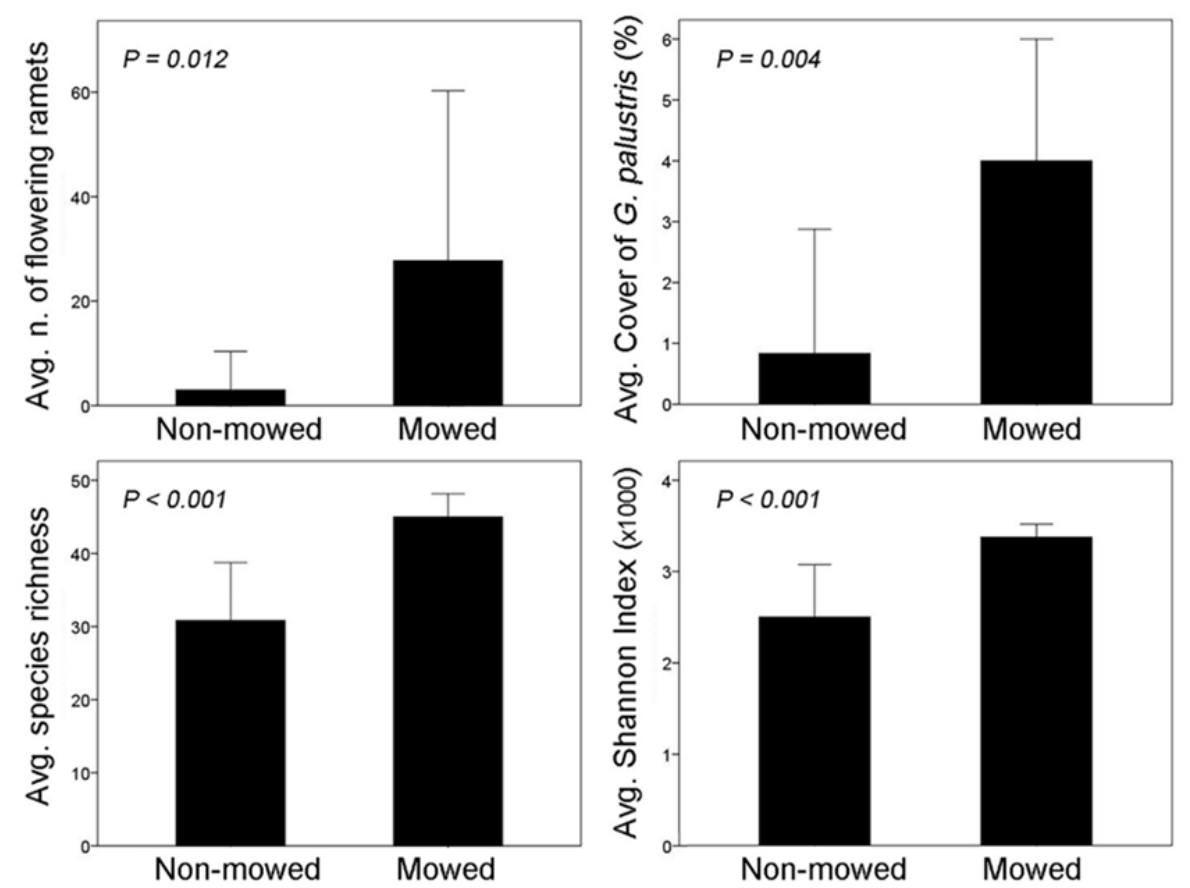

Figure 3 Comparison between mowed and non-mowed plots. Error bars represent double standard errors. Clockwise: G. palustris flowering ramets, G. palustris double standard errors. Clockwise: G. palustris flow
percentage cover, Shannon index and species richness.

relationship between the percentage cover of $G$. palustris, the cover of woody species and the mowing treatment, while a negative relationship was found with slope (Table 2). None of the abiotic and biotic variables were related to the number of flowering ramets of $G$. palustris. The cluster analysis clearly identified two groups corresponding to mowed and non-mowed plots (Figure 5), although two non-mowed plots (N5 and N6) clustered in the mowed group.

\section{Discussion}

Semi-natural habitats such as montane grasslands depend on traditional agricultural 
practices including mowing or extensive grazing. In Italy, many of these ecologically valuable mountain meadows are in private ownership, often abandoned and without any management strategy for habitat conservation. Under this scenario, competitive grasses such as Molinia arundinacea Shranck and other graminoid species are favoured due to their large seed production, vegetative propagation and leaf cover. Local plant communities need to be supported by using traditional land management regimes, to avoid the loss of habitats and species of conservation interest (e.g. those listed in the EC Habitat Directive 93/43/EEC like G. palustris (McDonald et al. 2000; Luoto et al. 2003) or other congeneric species like G. imbricatus (KostrakiewiczGieralt 2014). In the specific case presented here, the population of $G$. palustris on Mt. Grave is maintained through regular mowing of seminatural grasslands by the Dolomiti Bellunesi National Park (DBNP) authority. These land management activities are part of the DBNP's conservation plan. Similar management plans with regular mowing aimed towards the conservation of $G$. palustris populations exist in other European countries, too (e.g. for a large population at the German border of Lake Constance, Peintinger 2000). In our study site, the abandonment of traditional ovine grazing and regular mowing of montane grasslands led to a change in plant species composition and to a progressive encroachment of woody species. Even if the linear regression enlightened a positive correlation between G. palustris cover and woody species cover, we feel this result is due to the presence of young plants of Sorbus aria (L.)

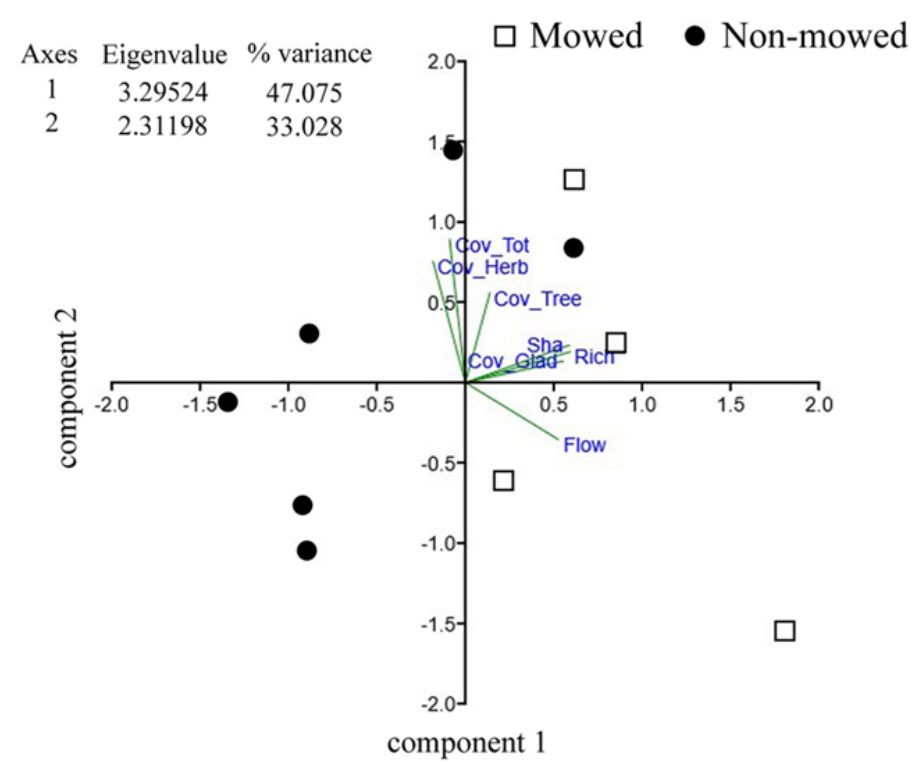

Figure 4 Principal Component Analysis (PCA). Biplot (on the first two axes) showing the distribution of type of plot (mowed $v s$. non-mowed) in relation to vegetation variables and the performance of $G$. palustris.

Table 2 Results of a multiple linear regression with variables of $G$. palustris as response variables and biotic and abiotic predictors. Significant effects $(P<0.05)$ are in bold.

\begin{tabular}{|c|c|c|c|}
\hline \multirow{2}{*}{ Response variable } & \multirow{2}{*}{ Predictors } & \multicolumn{2}{|c|}{ Statistics } \\
\hline & & $t$ & $P$ \\
\hline \multirow{5}{*}{ G. palustris flowering ramets } & Woody species cover (\%) & 1.216 & 0.807 \\
\hline & Herbs cover (\%) & -0.793 & 0.291 \\
\hline & Aspect & 0.721 & 0.472 \\
\hline & Slope & -1.329 & 0.255 \\
\hline & Mowing treatment & 2.031 & 0.112 \\
\hline \multirow{5}{*}{ G. palustris cover (\%) } & Woody species cover (\%) & $\mathbf{3 \cdot 3 4 4}$ & 0.029 \\
\hline & Herbs cover $(\%)$ & 1.944 & 0.124 \\
\hline & Aspect & 2.642 & 0.057 \\
\hline & Slope & $-3 \cdot 416$ & $\mathbf{0 . 0 2 7}$ \\
\hline & Mowing treatment & 5.147 & 0.007 \\
\hline
\end{tabular}

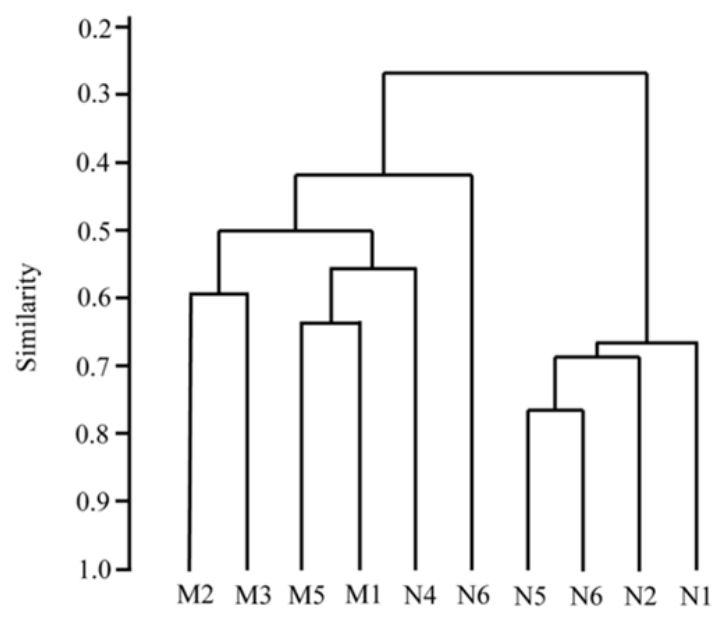

Figure 5 Cluster analysis of plots based on species percentage cover. $\mathrm{M}$ $=$ mowed plots; $\mathrm{N}=$ non-mowed plots. Note that plots $\mathrm{N}_{5}$ and $\mathrm{N} 6$ are the two non-mowed plots inside the mowed area. 
Crantz. and Amelanchier ovalis Medik. in the eastern mowed plots. In early stages of their life cycle, individuals of woody species do not seem to affect the performance of G. palustris, but if the mowing practice is suspended for a long period it is plausible that the consequent habitat change would undermine the survival of G. palustris in the area. The resumption of mowing for conservation purposes in our study area undertaken by the DBNP authority has halted the encroachment of woody species and has avoided a drastic change in plant composition. The population size of $G$. palustris is remarkable in terms of flowering ramets compared to literature data (see for example the populations studied in France and Switzerland by Daco et al. 2019). The mowed area shows a larger occurrence and higher density of $G$. palustris in terms of flowering ramets (as shown by GLM) and percentage cover (as shown by GLM and linear regression) than the non-mowed area just outside the park border. The missing consistency of correlation between mowing and number of flowering ramets in the linear regression could be due to the limited number of replicates. Conservation management of G. palustris in this type of grassland is correlated with population dynamics of many co-occurring species, and it has benefitted several other plant species of conservation interests. For instance, the study area is rich in locally protected species co-occurring with G. palustris like Asphodelus fistulosus L., Iris graminea L., Lilium bulbiferum L., Rhaponticum scariosum Lam. (protected in Veneto region) and species characterising policy habitats like Hippocrepis comosa L. subsp. comosa, Thymus pulegioides L., Koeleria pyramidata (Lam.) P.Beauv. but also orchids such as Dactylorhiza maculata (L.) Soó subsp. fuchsii (Druce) Hyl., which is characteristic of semi-natural dry grasslands. This result is consistent with results from nature reserves at the northern edge of the European Alps (Peintinger 1990; Quinger 2003). In addition, other locally valuable and restricted forbs were, Cirsium pannonicum (L.f.) Link, Danthonia decumbens (L.) DC., Geranium sanguineum L., Inula hirta L., Potentilla alba L., Serratula macrocephala Bertol., and Trifolium medium L. As shown by the cluster analysis, the two plots situated inside the mowed area (plots N5 and N6) show intermediate characteristics between mowed and non-mowed plots in terms of species richness and percentage cover of species. It is to speculate that the seed production of forbs in mowed areas had an influence on these two unmowed plots, by enriching the soil seed bank of forbs even if grasses and graminoids dominate the plant cover. G. palustris and many other forbs of montane grasslands show a transient behaviour in terms of seed longevity (Cerabolini et al. 2003), presenting also physiological dormancy. This fact highlights the role of the soil seed bank on the vegetation dynamics in such habitats. Considering the concept of "extinction debt", for which the extinction of a particular species is delayed after habitat fragmentation or degradation (Tillman et al. 1994), we may hypothesize that bulbs and the soil seed bank of G. palustris make this species more resilient to habitat degradation. Consequently, conservation actions like in this case mowing, could restore the population even with a limited plant cover. Moreover, the persistence of plant species through soil seed bank or other dormant dispersal units is also connected to the so-called "dark diversity" (Pärtel et al. 2011), the presence of a given species is sometimes only potential, and its survival is related to the effectiveness of the adopted restoration measures. Looking at the effectiveness of mowing, a recent study showed that positive effect of mowing on biodiversity (on both flora and fauna) is not related to mowing frequency (Talle et al. 2018). In non-productive grasslands, positive effects on the number of species and their percentage cover could be obtained through mowing every second or third year, while mowing once (or more often) per year did not produce sizeable advantages considering the higher operational costs. Therefore, the increase of competitive species (e.g. Molinia arundinacea Schrank, Sesleria caerulea (L.) Ard. subsp. caerulea) may be limited by non-frequent periodic mowing (Hájková et al. 2009). Late summer mowing in mountain meadows is currently perceived as economically disadvantageous by land owners, due to difficult access for mechanic devices and low hay quality and productivity. Nevertheless, the establishment of nature reserves, in the presented case of a Site of Community Importance, gives managing authorities the possibility to obtain additional funds for the management of nature conservation. 
Such funds might be provided by the European Agricultural Fund for Rural Development (EAFRD) as part of the EC's Common Agricultural Policy (CAP). In the specific case of Italy, grants might be provided by the regional authorities for agriculture (e.g. Veneto Agricoltura in Veneto, ERSAF in Lombardy) as part of the Rural Development Plan or by national authorities as funds for biodiversity conservation. Besides conservation-driven mowing, other conservation actions can be effectively used to restore or reduce the loss of plant diversity in semi-natural grasslands. As suggested by Muller (2002), moderate sheep grazing may be an alternative conservation measure. On the other hand, even if grazing limits the growth of graminoids, oligotrophic species of montane meadows could be disadvantaged by an increased nitrogen intake. Reintroduction of ovine grazing were tried in the DBNP, but led to dramatic changes in habitat composition and to the establishment of species-poor Nardus stricta L. prairies, especially in areas of livestock stationing (C. Lasen personal observation). Moora et al. (2007) showed similar results for the congeneric Gladiolus imbricatus L. in coastal meadows of Estonia, both cattle and sheep grazing led to higher damage of generative and vegetative plants compared to juveniles, which prevented an increase of population size and density. Grazing therefore seems a suitable tool for maintaining plant population dynamics (e.g. the ratio between mature/juvenile plants), but it should be applied once and alternated with mowing. Mowing or mixed grazing-mowing practices are also prescribed for other plant species protected at European level, such as Arnica montana L. in the Carpathians (Michler et al. 2004). Palatability of plant species for herbivores may play a role in conservation grazing practices as the target species should not be eaten by livestock (Rotar et al. 2011). Concerning the Italian policy species, other montane species reported by ISPRA (2016) deserve a more detailed examination of the effects of mowing on their conservation status, such as Lilium rubrum Lam. \& DC., Peonia officinalis subsp. banatica (Rochel) Soò, Crambe tataria Sebeok, Serratula lycopifolia (Vill.) A.Kern and Euphrasia marchesettii Wettst. ex Marches.

\section{Conclusions}

Managed areas showed a more complex vegetation structure and presence of species which are typical of EU policy habitats. At the same time, G. palustris benefitted from periodical mowing, showing higher number of flowering ramets and percentage cover in mowed areas than in nonmowed areas. Although the extent of the study area was limited to one nature reserve, the results obtained are particularly relevant taking into account that the conservation status of G. palustris in Italy is currently considered inadequate. We could show that multiple mowing per year was not necessary, while mowing every other year is recommended to maintain montane grasslands where traditional grazing and agricultural practices had been abandoned. Areas outside of the control of the Park authorities or in general outside SACs rarely benefit from adequate funds for conservation, and abandonment of traditional practices often result in loss of biodiversity. Ad hoc economic incentives for farmers and land owners (e.g. Rural Development Plan funds provided by the EC Common Agriculture Policy) may represent a further incentive for maintaining biodiversityrich semi-natural habitats outside protected areas.

\section{Acknowledgements}

Mowing activities in Mt. Grave are performed thanks to national funding provided by Ministero dell'Ambiente e della Tutela del Territorio e del Mare (direttiva ministeriale ex cap. 1551). This study was funded by Dolomiti Bellunesi National Park in the context of European 'Habitat' directive 92/43/CEE monitoring. Open access funding provided by Università degli Studi di Pavia within the CRUI-CARE Agreement. We are indebted to rangers (Reparto Carabinieri Parco Nazionale Dolomiti Bellunesi) of Pedavena and Candaten (BL) for logistic support during the field survey. The Grant of Excellence Departments, MIUR-Italy (articolo 1, commi 314 - 337 legge 232/2016) is gratefully acknowledged for the support to one of the authors (Prof. Thomas Abeli). Moreover, we would like to thank two anonymous reviewers for their invaluable comments on an earlier version of the manuscript. 
Open Access This article is distributed under the terms of the Creative Commons Attribution 4.0 International License (http://creativecommons. org/licenses/by/4.0/), which permits unrestricted use, distribution, and reproduction in any medium, provided you give appropriate credit to the original author(s) and the source, provide a link to the Creative Commons license, and indicate if changes were made.

\section{References}

Agnoletti M (2007). Guidelines for the Implementation of Social and Cultural Values in Sustainable Forest Management: A Scientific Contribution to the Implementation of MCPFEVienna Resolution 3. IUFRO Headquarters.

Balazsi A (2016) Grassland Management in Protected Areas. A Study on the Implementation of the EU Biodiversity Strategy in Certain Post-Communist Countries. Alfred Toepfer Natural Heritage Scholarships, Cluj Napoca, Romania.

Bilz M (2011) Gladiolus palustris. The IUCN Red List of Threatened Species. https://doi.org/10.2305/iucn.uk.20111.rlts.t162188a5555329.en

Buffa G, Carpenè $\mathrm{B}$, Casarotto $\mathrm{N}$, et al. (2016) Lista rossa del regionale delle piante vascolari. Regione del Veneto, Venezia, Italy.

Campagnaro $\mathrm{T}$, Trentanovi G, Sitzia $\mathrm{T}$ (2018) Identifying Habitat Type Conservation Priorities under the Habitats Directive: Application to Two Italian Biogeographical Regions, Sustainability 10: 1189. https://doi.org/10.3390/su10041189

Cerabolini B, Ceriani R, Caccianiga M, et al. (2003) Seed size, shape and persistence in soil: A test on Italian flora from Alps to Mediterranean coasts. Seed Science Research 13: 75-85. https://doi.org/10.1079/SSR2002126

Common Agriculture Policy.

https://ec.europa.eu/info/food-farming-fisheries/keypolicies/common-agricultural-policy/cap-glance_en

Czortek P, Delimat A, Dyderski MK, et al. (2018) Climate change, tourism and historical grazing influence the distribution of Carex lachenalii Schkuhr - a rare arctic-alpine species in the Tatra Mts. Science of the Total Environment 618:1628-1637. https://doi.org/10.1016/j.scitotenv.2017.10.001

Da Canal MT, Tornadore N, Marcucci R (2003) Biocoenotic and karyological characterization of four upspring critical taxa of the eastern Po Plain (North-Eastern Italy). Plant Biosystems 137: 21-27. https://doi.org/10.1080/11263500312331351291

Daco L, Maurice T, Muller S, et al. (2019) Genetic status of the endangered plant species Gladiolus palustris in the western part of its distribution area, Conservation Genetics 20:13391354. https://doi.org/10.1007/s10592-019-01213-0

Euro+Med (2019) Euro+Med PlantBase - the information resource for Euro-Mediterranean plant diversity. http://ww2.bgbm.org/EuroPlusMed, accessed 25/o6/2019.

European Agricultural Found for Rural Development. https://ec.europa.eu/agriculture/index_en

European directive 92/43/CEE (1992) Official Journal of European Communities, L 206, Vol 35, 22.

European Environmental Agency (2019) Gladiolus palustris Gaudin. Available at

https://eunis.eea.europa.eu/species/186576, accessed on February 2020.

Fenu G, Bacchetta G, Giacanelli V, et al. (2017) Conserving plant diversity in Europe: outcomes, criticisms and perspectives of the Habitats Directive application in Italy. Biodiversity and Conservation 26: 309-328.

https://doi.org/10.1007/s10531-016-1244-1

Hájková P, Hájek M, Kintrová K (2009) How can we effectively restore species richness and natural composition of a Moliniainvaded fen? Journal of Applied Ecology 46: 417-425.

https://doi.org/10.1111/j.1365-2664.2009.01608.x

Halada L, Evans D, Romão C, Petersen JE (2011) Which habitats of European importance depend on agricultural practices? Biodiversity and Conservation 20: 2365-2378 https://doi.org/10.1007/s10531-011-9989-z

Hammer $\varnothing$, Harper DAT, Ryan PD (2001) PAST: Paleontological statistics software package for education and data analysis. Palaeontologia Electronica 4: 9.

Horak J, Safarova L (2015) Effect of reintroduced manual mowing on biodiversity in abandoned fen meadows. Biologia 70 (1): 113-120. https://doi.org/10.1515/biolog-2015-0009

ISPRA, Istituto Superiore per la Protezione e la Ricerca Ambientale (2016) Manuali per il monitoraggio di specie e habitat di interesse comunitario (Direttiva 92/43/CEE) in Italia: specie vegetali, ISPRA e Ministero dell'Ambiente e della Tutela del Territorio e del Mare. Rome, Italy.

Joyce CB (2014) Ecological consequences and restoration potential of abandoned wet grasslands. Ecological Engineering 66: 91-102. https://doi.org/10.1016/j.ecoleng.2013.05.008

Kiehl K, Kirmer A, Donath TW, et al. (2010) Species introduction in restoration projects - evaluation of different techniques for the establishment of semi-natural grasslands in Central and Northwestern Europe. Basic and Applied Ecology 11:285-299.

https://doi.org/10.1016/j.baae.2009.12.004

Kostrakiewicz-Gierałt K (2014) The variability of selected features of Gladiolus imbricatus L. in relation to successive stages of meadow communities following the mowing cessation. Polish Journal of Ecology 62(2):307-321. https://doi.org/10.3161/104.062.0210

Lasen C, Argenti C (2000) The flora of Dolomiti Bellunesi National Park. Studi e Ricerche. Feltre, Italy. (In Italian)

Lasen C, Tomaselli M, Scariot A, et al. (2018a) Floristic composition, site conditions and diversity of poet's daffodil (Narcissus radiiflorus Salisb.) hay meadows in the Venetian Pre-Alps and outer Dolomites (N-Italy): implications for conservation and restoration. Plant Biosystems 152: 12361247. https://doi.org/10.108o/11263504.2018.1435578

Lasen C, Tommaselli M, Scariot A, et al. (2018b) Narcissus in fen meadows: an endangered resource. Frammenti 8: 78-105. (In Italian)

Regional law n. 53, Veneto region, $15^{\text {th }}$ November 1974.

Luoto M, Rekolainen S, Aakkula J, Pyka J (2003) Loss of plant species richness and habitat connectivity in grasslands associated with agricultural change in Finland. Ambio 32: 447-452. https://doi.org/10.1579/0044-7447-32.7.447

MacDonald D, Crabtree JR, Wiesinger G, et al. (2000) Agricultural abandonment in mountain areas of Europe: environmental consequences and policy response. Journal of Environmental Management 59: 47-69. https://doi.org/10.1006/jema.1999.0335

Metzing D, Hofbauer N, Ludwig G, Matzke-Hajek G (2018) Rote Liste gefährdeter Tiere, Pflanzen und Pilze Deutschlands, Band 7: Pflanzen. Bundesamt für Naturschutz, Bonn-Bad Godesberg.

Michler B, Kathe W, Schmitt S, et al. (2004) Conservation of Eastern European Medicinal plants: Arnica montana in Romania. Bulletin USAMV-CN, Seria Agricultura 60: 228230.

Middleton BA, Holsten B, Van Diggelen R (2006) Biodiversity 
management of fens and fen meadows by grazing, cutting and burning. Applied Vegetation Science 9: 307-316.

https://doi.org/10.1111/j.1654-109X.2006.tboo680.x

Moser D, Gygax A, Bäumler B, et al. (2002) Liste Rouge des fougères et plantes à fleurs menacées de Suisse. OFEV, Bern, Switzerland.

Muller (2002) Diversity of management practices required to ensure conservation of rare and locally threatened plant species in grasslands: a case study at a regional scale (Lorraine, France). Journal of Applied Ecology 46: 417-425. https://doi.org/10.1023/A:1016049605021

Ostermann OP (1998) The need for management of nature conservation sites designated under Natura 2000. Journal of Applied Ecology 35: 968-973.

https://doi.org/10.1111/j.1365-2664.1998.tbooo16.x

Parolo G, Abeli T, Rossi G (2011) Large-scale heterogeneous cattle grazing affects plant diversity and forage value of Alpine species-rich Nardus pastures. Grass and Forage Science 66: 541-550. https://doi.org/10.1111/j.1365-2494.2011.00810.x

Pärtel M, Szava-Kovats R, Zobel M (2011) Dark diversity: shedding light on absent species. Trends in Ecology \& Evolution 26(3): 124-128.

https://doi.org/10.1016/j.tree.2010.12.004

Plan for Rural Development 2014-2020, paragraph 8: measures, Veneto Agricoltura.

Peintinger M (1990) Fluctuations of rare plant species in fen meadows in the western area of Costance lake. Carolinea 48: 69-84. (In German)

Peintinger M (2000) Long-term variation of geophytes flowering in fen meadows: time or water effect?

Bauhinia 14: 33-44. (In German)

Peter M, Gigon A, Edwards PJ, et al. (2009) Changes over three decades in the foristic composition of nutrient-poor grasslands in the Swiss Alps, Biodiversity and Conservation 18:547-567. https://doi.org/10.1007/s10531-008-9521-2

Quinger B (2003) Effizienzkontrollen zur StreuwiesenBewirtschaftung im Rahmen des Programms "Erschwernisausgleich", Phase VII.- Report produced for the Bayer. Landesamt für Umwelt: $50 \mathrm{~S}$.

Rossi G, Orsenigo S, Montagnani C, et al. (2016) Is legal protection sufficient to ensure plant conservation? The Italian Red List of policy species as a case study. Oryx 50: 431-436. https://doi.org/10.1017/So03060531500006X

Rotar I, Pacurar F, Bogdant A (2011) The Influence of Technological Inputs on Arnica Montana L, Bulletin USAMVCN. Agriculture 68:314-317.

Sburlino G, Bracco F, Buffa G, Andreis C (1995) I prati a Molinia caerulea (L.) Moench della Pianura padana: sintassonomia, sincorologia, sinecologia. Fitosociologia 29:67-87.

Shannon CE (1948) A mathematical theory of communication. Bell System Technical Journal 27: 379-423,623-656. https://doi.org/10.1002/j.1538-7305.1948.tbo1338.x Special Area of Conservation (SAC). https://www.minambiente.it/pagina/regione-veneto-o

Stampfli A, Zeiter M (1999) Plant species decline due to abandonment of meadows cannot easily be reversed by mowing. A case study from the southern Alps. Journal of Vegetation Science 10: 151-164. https://doi.org/10.2307/3237137

Swacha G, Botta-Dukát Z, Kącki Z, et al. (2018) The effect of abandonment on vegetation composition and soil properties in Molinion meadows (SW Poland). PLoS ONE 13(5): e0197363.https://doi.org/10.1371/journal.pone.0197363

Tälle M, Deák B, Poschlod P, et al. (2018) Similar effects of different mowing, frequencies on the conservation value of semi-natural grasslands in Europe. Biodiversity and Conservation 27: 2451-2475. https://doi.org/10.1007/s10531-018-1562-6

Tallowin JRB, Rook AJ, Rutter SM (2005) impact of grazing management on biodiversity of grasslands. Animal Science 81: 193-198. https://doi.org/10.1079/ASC50780193

Tilman D, May R, Lehman C, Nowak M (1994) Habitat destruction and the extinction debt. Nature 371: 65-66. https://doi.org/10.1038/371065ao

Török P, Vid E, Deák B, et al. (2011) Grassland restoration on former croplands in Europe: an assessment of applicability of techniques and costs. Biodiversity and Conservation 20:23112332. https://doi.org/10.1007/s10531-011-9992-4

Valkó O, Török P, Matus G, Tóthmérész B (2012) Is regular mowing the most appropriate and cost-effective management maintaining diversity and biomass of target forbs in mountain hay meadows? Flora 207: 303-309. https://doi.org/10.1016/j.flora.2012.02.003

Van der Maarel E (2015) Vegetation Ecology, Blackwell Publishing, Hoboken, USA.

Wiesmair M, Otte A, Waldhardt R (2017) Relationships between plant diversity, vegetation cover, and site conditions: implications for grassland conservation in the Greater Caucasus, Biodiversity and Conservation, 26: 273-291. https://doi.org/10.1007/s10531-016-1240-5

Witkowski ZJ, Król W, Solarz W (2003) Carpathian List of Endangered Species. WWF and Institute of Nature Conservation, Polish Academy of Sciences, Europress, Krakow, Poland. 